\title{
Sarolta Tóth
}

\section{"Doorways to things beyond"}

\section{The question of religion in Walter Pater's works, with a special focus on Marius the Epicurean}

During the $19^{\text {th }}$ century the erosion of the Christian tradition ${ }^{1}$ and the individual's secure place within it made it necessary for artists and thinkers to reinterpret the human condition and to find an adequate framework for this reinterpretation. The task which the Romantic generations faced was the redefinition of their relationship to both religion and art. Therefore, in the Romantic Age, a period of transition into Modernism, the harvest of a long process, started in the $17^{\text {th }}$ century and nurtured during the Enlightenment, was finally reaped. "Most of what now passes with us for religion and philosophy will be replaced by poetry:" Matthew Arnold's famous statement ${ }^{2}$ captures precisely this Romantic tendency. Although the passage of time has refuted his prophecy, the attacks of writers like T. S. Eliot against Arnold are not wholly justified, because this remark, even if wide of the mark, still contains a realistic reference to the human condition. Human beings, he says in the same passage, are in need of consolation: "We have to turn to poetry to interpret life for us, to console us, to sustain us."

In hindsight, we can see that Arnold was right in that humanity does need consolation, and if religion does not provide universally accepted parameters any longer, other things will take its place. For the Romantics it was nature and art that acquired profound spiritual significance: nature becoming a source of

\footnotetext{
A s:gnilicaint step in this direction was the publication of Darwin's Origin of Species in 1859, and the subsequent rise of agnosticism.

"Matther Arnold. "The Study of Poetry." Essays in Criticism. London: Macmillan, 1925, p. 2-3.
} 
mystical experience, and the artist, most often the poet, taking the role of initiator into spirituality. These developments within Romanticism were carried to the extreme in Modernism. As Wordsworth in The Prelude uses the quasi-religious language of devotional poetry in his poetic quest for identity (the self remaining the only stable phenomenon among the loss of certainties), so James Joyce uses Christian liturgical language to describe poetic inspiration in $A$ Portrait of the Artist as a Young Man (the "priest of eternal imagination transmuting the daily bread of experience into the radiant body of everliving life." ${ }^{3}$ ).

Around the end of the $19^{\text {th }}$ century, this high appraisal of art led to the aesthetic movement, signalled first of all by the names of Walter Pater and Oscar Wilde. In spite of the fact that the view of Pater as the "guru of aestheticism" mostly passé in scholarly circles, he is seldom seriously dealt with in the context of his relationship to religion. It seems, however, that Pater was as preoccupied with the question of religion as most Romantic and early Modernist writers. On the following pages I will examine in what ways this preoccupation shaped his art.

Pater's notorious Conclusion to his collection of essays on The Renaissance appeared in 1873 and immediately earned him the label of Epicurean rebel, enemy of the traditional beliefs held by the Church. Even today, scholars, not unjustifiably, use this text to demonstrate the author's precocious Modernism and even Postmodernism. Talking about the impossibility of certain knowledge due to the perpetual flux of physical reality around us, and to the isolation of the individual ("each mind keeping as a solitary prisoner its own dream of a world") Pater certainly seems to reflect the anxiety of a modern mind.

F. C. McGrath points out that Pater's influence was twofold, leading into two distinct directions: besides his negative notions of perpetual change his lifework was imbued with "more positive yearnings to achieve through art, culture and religion some stability amid the flux." The modernist paradigm that he constructed out of Pater's texts, however, relies heavily on the "negative" side, as do most other analyses of Pater's works. McGrath's concentration on the patterns of subjectivity, relativism, scepticism, primacy of sensory perception etc.

\footnotetext{
${ }^{3}$ James Joyce. A Portrait of the Artist as a Young Man. Wordsworth Classics, 1992, p. $170 \mathrm{ff}$.

"Jules Lubbock. "Walter Pater's Marius the Epicurean. The Imaginary Portrait as Cultural History." Journal of the Warburg and Courtauld Institutes 46 (1983) 166-190, p. 166.

SWalter Pater. "Conclusion." The Renaissance. Studies in Art and Poetry. Oxford New York: Oxford University Press, 1986, p. 151.

${ }^{6}$ F. C. McGrath. The Sensible Spirit. Walter Pater and the Modernist Paradigm. Tampa: University of South Florida Press, 1986, p. 15.
} 
is convincing in that this was the heritage of this great synthesiser which actually flowed over into the intellectual climate of his successors, the early Modernists. Admittedly, this makes the interpretation of his Marius the Epicurean, in which Pater made the most successful attempt at achieving an artistic and existential wholeness and harmony, quite difficult. Jules Lubbock claims, for instance, that the reading of Marius as a "corrective statement" of Pater's personal philosophy ${ }^{7}$ would be an oversimplification of the issues, as it was far from Pater's intellectual temperament to present any "formal thesis." ${ }^{8}$ Lubbock argues that Pater presented doctrines with so masterly a detachment that his own views were almost impossible to determine, and he quotes one of Pater's pupils, who remarked that Pater's ideas remained "very much a mystery, even after Marius the Epicurean."

No wonder then, that we find so many opposing statements and interpretations in the literature on Walter Pater. Any great intellect, especially in such an age of transition and turmoil, is contradictory and paradoxical in his thinking, therefore the result of different approaches to his work will be especially determined by the chosen perspective. Gerald Monsman, for instance, in his book Walter Pater's Art of Autobiography ${ }^{10}$ has chosen a psychological approach - influenced by Freud and Jung, but also by deconstructionists pointing out that the patterns found in Pater's fiction are grounded in his early childhood; whereas Jules Lubbock argues that to place too much emphasis on the autobiographical aspect of Marius and Pater's other imaginary portraits is questionable. Instead, he perceives Marius as cultural history, analysing the influence of Hegel and J. S. Mill in Pater's thinking. He concludes by saying that more recent commentators have come to regard Pater's work "as literature rather than cultural history," but abandoned to literary critics it has been misinterpreted. ${ }^{11}$

\footnotetext{
${ }_{8}^{7}$ Jules Lubbock, p. 168.

${ }^{8}$ In a letter Pater writes: "As regards the ethical drift of Marius [...] I did mean it to be more antiEpicurean than it has struck you as being" (The Letters 78.22 July. 1883, p. 52) but, as Lubbock points out, Pater went on to say that he was none the less glad "that you have mistaken me a little on this point, as I had some fears that I might seem to be pleading for a formal thesis..." Jules Lubbock, p. 168.

"Edward Manson. "Recollections of Walter Pater." Oxford Magazine 25 (7 November 1906), p. 61. Quoted in Jules Lubbock, p. 169.

${ }^{10}$ Gerald Monsman. Walter Pater's Art of Autobiography. New Haven and London: Yale University, 1980.

"Jules Lubbock, p. 190.
} 
In contrast to Monsman and Lubbock, I will examine Pater's works strictly as texts of literature. Though it is an important critical task to assign the place of an author in the context of the history of ideas, sometimes it is at least as important to direct a fresh inquiry at the literary works themselves, and let their present impact act on our imagination and on our deepest human aspirations.

The present study takes its basic assumption from Northrop Frye, who based his theoretical work on "the assumption of total coherence" 12 in literature, on the hypothesis that "literature is not a piled aggregate of 'works,' but an order of words." $\mathrm{My}$ aim is to look for archetypal patterns, and to show the drift of the work, in this case, Marius the Epicurean towards a "centre of imaginative experience." 14

Marius can be described as a search or quest, led by the desire to make sense of the human condition. As this is one of the common aims of art, philosophy and religion, examining the interaction of artistic and existential/religious aspects can be expected to cast light on the work in question. The archetypal force of the quest pattern itself may have led Pater to blend his aestheticism with existential and spiritual concerns in this story.

Marius, as a "history of the soul," begins with Marius's religious experience of early childhood (observance of the old Roman religion "sustained by a native instinct of devotion" [p. 38 $]^{15}$ ) and ends on the threshold of another possible religious experience: an encounter with early Christianity in Rome. The hunger for making sense of reality will accompany Marius on his spiritual journey. Once a schoolboy in Pisa, urban life and his friendship with the poet Flavian leads to the abandonment of the old family beliefs, and to the adoption of a kind of "undergraduate aestheticism" (Lubbock). The search for a philosophical articulation of his position follows later; at this stage it is described by Pater simply as a "spirit of unbelief," the egotism and eagerness for experience so typical of young people, which often leads to "early corruption" (p. 65). Participating in Flavian's artistic activities, Marius discovers the beauty and the pleasure springing from the making and the enjoyment of art, specifically literature. But then his friend's death brings into focus his never ceasing awareness of the "tyrannous

\footnotetext{
${ }^{12}$ Northrop Frye. Anatomy of Criticism. London: Penguin Books, 1990, p. 16.

${ }^{13}$ Frye, p. 17.

${ }_{11}^{14}$ Frye, p. 117.

15 All parenthesised references are to this edition: Walter Pater. Marius the Epicurran. London: Penguin Books, 1985.
} 
reality of things visible" (p. 62), which in turn, awakes in him the need for severer, philosophical reasonings. He draws on the philosophies of Heraclitus and Aristippus (founder of Cyrenaic philosophy), and the position he articulates is basically the same as that expressed by Pater in the Conclusion: a "philosophy of the despair of knowledge" (p. 99), built on the notion of permanent change ("flux"), and the consequent call to "fall back upon direct sensation," to be "absolutely virgin towards experience," to become a "perfect medium of perception" (pp. 109-115). However, the drama of the human condition is that this desire - "to burn always with this hard, gemlike flame, to maintain this ecstasy" $^{16}$ - is unattainable, and to capture eternity in a moment of sensory experience is doomed to failure because of our finiteness in time. I will now consider some of those ancient elements in the human experience which question the pursuit of pure aestheticism and are powerfully expressed in Marius and elsewhere in Pater's works.

\section{THE REALITY OF EVIL}

Witnessing the cruel slaughter of animals in the Roman arena, and the indifference of the Stoic emperor Marcus Aurelius to the sight, Marius becomes painfully aware "of a crisis in life, in this brief, obscure existence, a fierce opposition of real good and real evil around him" (p. 170). It is not only the Emperor's Stoic asceticism which offends "Marius's Cyrenaic eagerness to taste and see and touch" (p. 147), but even more the inability of Stoicism to handle the question of evil. Indeed, Marcus Aurelius's ascetic indifference will break down at the first real trial: his children's sickness. On the other hand, the Epicurean aesthete will also avert his eyes in face of the obscurity of existence, in other words, he will avoid the question of evil.

Pater's moral preoccupations, most clearly expressed in Marius's spiritual development, were perfectly in line with earlier Romantic dilemmas concerning the problem of evil. Although the Romantic tradition was characterised by the belief in the perfectibility of man and in the infinite possibilities of human nature, it has also been pointed out that the question of evil and its anthropological interpretation was one of the fundamental problems of Romantic thinkers. Evil in the world, and the experience of $\sin$ and guilt led to a recognition of the finiteness

${ }^{16}$ Walter Pater. "Conclusion," p. 152. 
and limitation of human experience. ${ }^{17}$ Driven by this dilemma, both Coleridge and Wordsworth finally renounced pantheistic freedom and embraced Christian orthodoxy, the latter giving poetic expression to his choice in his Ode to Duty (Me this unchartered freedom tires / I feel the weight of chance desires). ${ }^{18}$ Although that kind of commitment seemed to be incompatible with Pater's temperament (as we will see later in Marius), the anxiety can be similarly traced back to the loss of a religious framework.

The acute recognition of the problem of morality leads Marius to emphasise the moral component in Cyrenaic philosophy, which will result in the curtailment of the absolute individualism of his own youthful Epicureanism. To find some common moral ground, he is compelled to modify his earlier creed of the momentary, sensible apprehension of the individual being "the only standard of what is or is not" (p. 109). In other words, he realises the need to get beyond the cell of one's own personality, which he has condemned as daydreaming earlier (p. 117). The movement beyond subjectivity, in turn, will call for a modification or curtailment of his concept of personal freedom, "in concession to the actual manner, the distinctions, the enactments of that great crowd of admirable spirits, who have elected so, and not otherwise, in their conduct of life" (p. 188).

The moral awareness of an aesthete like Pater will inevitably bring into focus the question of the ethical in art. Thus, Pater was understandably preoccupied with the "entanglement of beauty with evil," as he was acutely aware of the "fallenness of sensuous experience," the "dubious, double root" of all artistic creation and aesthetic enjoyment. ${ }^{19}$ Monsman points to the presence of a paradoxical figure, the Archangel in Pater's writings, who is a divine epiphany and a murderous lover at the same time: "an ambiguous force malign and protective." In art there is always a dangerously close wrestling with evil, and so ultimately, with death. ${ }^{20}$

\footnotetext{
${ }^{17}$ Analysing the episode of stealing a boat when a child in Book I of The Prelude, Ágnes Péter points out that for William Wordsworth the recognition of infinite freedom was accompanied by feeling guilt and the consequent limits of human life. Ágnes Péter. Roppant szivárvány. A romantikus látásmódról. Budapest: Nemzeti Tankönyvkiadó, 1996, p. 139.

${ }^{18}$ Péter, pp. $145-150$.

${ }^{19}$ Gerald Monsman, p. 140.

${ }^{20}$ This preoccupation can be traced back to Romanticism, see Ágnes Peter's remark on Keats: the creative process itself is one of the deepest form of knowing, coming close to a kind of death. (Ágnes Péter, p. 171.)
} 


\section{DEATH}

Most of Pater's imaginary portraits end with the death of the protagonist. The force that moves Marius onwards from one stage of development to the next is death. Death thus becomes a structural, organising principle in the work: first the death of his mother (followed by his departure from the family villa), the death of Fabian (followed by Marius first serious philosophical search); and finally Marius's own death. His life "had been something of a meditatio mortis, ever facing towards the act of final detachment" (p. 288) .

Of course evil, sin and death are aspects of the same ancient reality in a culture informed by the biblical tradition. They upset the Greek "balance" and mar ideal beauty; they constitute the existential rupture, the hindrance of that wholeness and harmony towards which the human search is directed. We learn that the first death in Marius's life (his mother's) makes him a questioner. This is the cause of the fundamental dilemma of aesthetes like Pater, who are haunted by the "pagan sadness," by the sentiment that the pleasures of the senses slip out of our hands, in spite of our yearning for their permanence. Describing in his essay on Winckelmann a universal pagan sentiment, the broad foundation of all religions, Pater beautifully writes: "It is with a rush of home-sickness that the thought of death presents itself. He would remain at home for ever on the earth if he could." Marius, at Flavian's deathbed, tries to "fix in his memory every detail, should any hour of forgetfulness hereafter come to him with the temptation to feel completely happy again" (p. 101).

For Pater a most glorious attempt for home-making on the earth was the Renaissance. "It helped man onward to that reassertion of himself, that rehabilitation of human nature, the body, the senses, the heart, the intelligence..." He saw it

as a counterpoise to the increasing tendency of medieval religion to depreciate man's nature, to sacrifice this or that element in it, to make it ashamed of itself, to keep the degrading or painful accidents of it always in view... ${ }^{22}$

(my italics)

\footnotetext{
${ }^{21}$ Walter Piter, "Winckelmann." The Renaissance, p. 129.

22. Waiter Pater. "Pico della Mirandola." The Renaissance, p. 27.
} 
But in these quotes from his essay "Pico della Mirandola" the basic paradox of humanness is exposed again: the degrading and painful elements are there, and making sense of life is to reunite what the degradation has separated. In other words, it is necessary to face evil and deal with it so that the reassertion of humanness will become possible. The unattainable purpose is to reconcile the yes and the no, the two equally necessary answers to humanness. Although Pater was undoubtedly more attracted to the "yes" pole of the paradox, in at least one of the imaginary portraits we see an extreme example of asceticism. Sebastian van Storck, in his detached pantheism inspired by Spinoza, makes an attempt to achieve the "equilibrium" by "tabula rasa," by completely dying to self. His intellectual tendencies

seemed to necessitate straightforward flight from all that was positive. He seemed, as one may say so, in love with death; preferring winter to summer; finding only a tranquillising influence in the thought of the earth beneath our feet cooling down for ever from its old cosmic heat... ${ }^{23}$

Sebastian, with his strange inverse mysticism or via negativa, can even be conceived of as the counterpart of most of Pater's other heroes (including Marius) who live under the spell of the "sense of the splendour of our existence and of its awful brevity." ${ }^{24}$

Becoming thus aware of the "degrading and painful" elements of life (i. e. evil and death), Marius realises the restrictions of his philosophy.

It is one of those subjective and partial ideals, based on vivid, because limited, apprehension of the truth of one aspect of experience (in this case, of the beauty of the world and the brevity of man's life there) which it may be said to be the special vocation of the young to express.

Marius's life can also be seen as a metaphor for the development of humanity in that his youth can be conceived of as parallel with the antique Greek world, the youth of humanity, as Pater has written elsewhere: "Let us not regret that this unperplexed youth of humanity, satisfied with the vision of itself, passed, at the due moment, into a mournful maturity..." 25

${ }^{23}$ Walter Pater. "Sebastian Van Storck." Imaginary Portraits. London: Macmillan and Co., 1905, pp. 98-99.

24 Walter Pater. "Conclusion," p. 152.

${ }^{25}$ Walter Pater. "Winckelmann." The Renaissance, p. 134. 
The "mournful maturity" Pater refers to here is of course Christianity, with which Marius will be acquainted in the final stage of his life. His encounter with Christianity is preceded and prepared by an exposure to Apuleius and his Platonism, which seems to him somewhat too facile in its assumption of a "celestial ladder from heaven to earth" (p. 224). In Marius's eyes it is the kind of mystical vision which fails to do justice to the actual world and to the human body, thus representing the philosophical opposite of Epicureanism. After these extremes, the early Christian experience, mediated to him by his new friend, Cornelius, a young Roman soldier, seems to have a synthesising power hitherto unknown during his philosophical and existential search. I will dedicate the rest of my paper to the analysis of different aspects of this experience, concentrating on Marius's visit to an early Christian act of worship at the Roman matron Cecilia's house.

\section{THE DESIRE FOR UNITY}

Gerald Monsman has convincingly demonstrated that some qualities of the Paterian text (Marius) tend towards postmodernism (its ultrareflective nature, "the ceaseless shuttling back and forth between all possible levels" ${ }^{26}$ etc.), yet the yearning for unity, the possibility of which is denied by Postmodernism, is a Romantic quality, carried to its final point in the Modernist attempts at totality.

It dissolves, diffuses and dissipates, in order to recreate; - Coleridge wrote of the secondary imagination - or where this process is rendered impossible, yet still at all events it struggles to idealize and unify.

(my italics).

Monsman himself has remarked that in Marius visionary wholeness takes the place of the disintegrating flux, and at any rate, Pater's dialectic is far from Derrida's defiant playfulness. Instead, it is a dramatic wrestling to make sense of experience and find a centre for it.

As I have stated earlier, art and religion are often employed to the same end: to recreate the broken unity, to regain the lost harmony (Monsman), to find a centre, over and against the disintegrating effects of the world of the flux. Monsman is right to point out that Pater has glimpsed this elusive wholeness in

is Gerald Monsman, p. 6. 
the aesthetic object, and that by idealising life, art for him has achieved "the conquest and reconciliation [...] between the antinomies of life and death, beauty and horror, the real and the imaginary..." ${ }^{27}$ Yet the text of Marius suggests that Marius/Pater yearned for more than the elusive wholeness of aesthetics. By imaginatively depicting a sacred moment of history, in Marius the Epicurean Pater seems to have created a myth of the perfect integration of culture, art and religion. The point about this sacred moment is exactly that these aspects cannot and should not be separated. Although it has been pointed out by many scholars ${ }^{28}$ that Marius's experience of the church at Cecilia's house, his observance of the liturgy is primarily aesthetical, it is powerful enough to fill him with "hope against hope," and to awake the moral drives inherent in his nature. Similarly, thoug:? we know that the Cecilia in Marius is a complete fabrication, Pater, according to Lubbock, "seems to have aimed to produce a conjectural reconstruction of a real woman, some of whose attributes might have led to her adoption as the patron saint of music, just as others might have given rise to the ascetic martyr of the legend" (my italics). ${ }^{29}$

Cecilia's house endowed with this mythic quality becomes for Pater the great organising metaphor for art and life; a single vision of unity: an artistic ideal and a transcendent presence, appearing, however elusively, in one single form. Pater, all through his life's work, searched for a door leading out of the hopelessly relativistic world of the senses ("Marius [...] yearning [...] in that hard world of Rome, and below its unpeopled sky, for the trace of some celestial wing across it," or later: "a certain longing for escape [...] for a lifting, from time to time, of the actual horizon" [p. 233]), and in the vision at Cecilia's house, he seems to have caught a glimpse of a wider reality.

The whole episode is introduced by a beautiful unity of imagery: first, quoting Swedenborg, Pater speaks of the unity of the soul and her house with all the visual aspects of a concrete building, and these visual objects themselves become "powers of apprehension," and thus "doorways to things beyond," "the germ or rudiment of certain new faculties, by which she, dimly yet surely, apprehends a matter lying beyond her actually attained capacities of spirit and sense" (pp. 225-226). Thus a few minutes later the quite ordinary conversation between Marius and Cornelius acquires metaphorical and symbolic significance:

\footnotetext{
${ }^{27}$ Gerald Monsman, p. 33.

${ }^{28}$ See Michael Levey's Introduction to the Penguin edition of Marius the Epicurean (1985).

${ }^{29}$ Jules Lubbock, p. 187.
} 
Cornelius, opening the door to another dimension, and the question "Would you like to see it?," points towards a possible reconciliation between sense and spirit, between the here and the beyond. On the second occasion Marius arrives at the time of the mass, and has a chance to follow the liturgy, which, as a religious act, has the same significance as a work of art: it builds a bridge between the visible and the invisible, apprehending unseen realities through the senses. It is like the activity of the painter who sets a "window or open doorway in the background of his picture" (p. 233). ${ }^{30}$

By the event of the mass, the supreme Christian ritual of European culture, the story acquires archetypal significance in the last, climactic section. As I interpret Northrop Frye's theory of archetypes, a literary work has archetypal significance if it expresses a form of the quest myth, pointing at deep and common human desires for fulfilment. The reason for this is that primitive ritual is interpreted by Frye not simply as an attempt to influence natural processes but as an attempt "to synchronize human and natural energies," i.e., to build up what we call civilisation, to make "a total human form out of nature," and this specifically human pursuit is impelled by the desire for redemption, which for Frye basically means the desire for human fulfilment and for a better world than the actual. This is exactly Marius's desire: "innate and habitual longing for a world altogether fairer than that he saw" (p. 61), "the vision of a perfect humanity in a perfect world" (p. 293). The basic expression of this desire is human dream (the "conflict of desire and actuality"), and "the union of ritual and dream in a form of verbal communication is myth." ${ }^{31}$ Myth is the source of religion, and of literature in a later phase, which also means that what Frye calls the "central quest myth" ("a central narrative around a figure who is partly the sun, partly vegetative fertility and partly a god or archetypal human being" 32 going through some king of a fall and death, then revival or resurrection) is common to both literature and to the major religions. The common element, I would say, is the archetypal desire for redemption or fulfilment, and it is this that has driven Marius up to the point I

\footnotetext{
${ }^{30}$ The union of visible and invisible by Christian liturgy is stressed in an earlier piece of fiction (The Child in the House): "he [Florian] remembered gratefully how the Christian religion [translates] so much of its spiritual verity into things that may be seen..." Quoted in Michael Levey's Introduction to the Penguin edition of Marius the Epicurean, 1985.

${ }^{31}$ Northrop Frye. Anatomy of Criticism, pp. 104-112.

${ }^{32}$ Northrop Frye. "The Archetypes of Literature." Modern Theories of Literature. Ed. David Lodge. London New York: Longman House, 1972, p. 429.
} 
have shown above. His dream ${ }^{33}$ is not that of an individual dreaming his own world, but by the power of art - independently of authorial intentions - has been gathered up into the ancient rituals and dreams of humanity and thus given the form of myth. The archetype of tragedy is the myth of the dying god(s) as part of the quest myth. ${ }^{34}$ So with the re-enactment of the death of Christ (the mass) the story of Marius approaches the mythic mode (the first historic mode according to Frye, the starting point of literature) to end up masterfully in tragic irony: Marius's death "by accident." Paradoxically, however, his death, with all the irony, is again a repetition of the ritual, and Marius is unmistakably a Christfigure (the two events could even be perceived as being in a typological relation). Thus we can venture to say that Marius the Epicurean exhibits some of the qualities of the greatest modern literature, namely those of Joyce and Kafka, because here we can witness the same return of modern irony to myth which Frye pointed out in connection with those writers. ${ }^{35}$ This seems to mean that the

\footnotetext{
${ }^{33}$ The epigraph on the title page of "Marius" (from Lucian: "A winter dream, when the nights are longest") has been interpreted in several ways. Monsman characteristically thinks that "to call the novel a dream is to affirm its nature as artifice - as a structure turning back upon itself" (p. 57). This statement can be applied to much literature, and does not necessarily contradict my interpretation, i.e. that the dream element in great literature corresponds to deep and common human desires.

${ }^{34}$ Frye's description of the quest myth and his whole theory of archetypes admittedly owes much to J. G. Frazer's work, especially to The Golden Bough. His output "is indispensable for a book like this," Frye wrote in his first study on the Bible (The Great Code: The Bible and Literature. San Diego New York London: A Harvest Book, Harcourt Brace \& Company, 1982, p. 35), but then he also clearly distinguished his own notion of literary archetype from both Frazer's anthropological and Jung's psychological approach (see Anatomy of Criticism, pp. 108-112, and The Great Code, pp. 3538). It is not possible to present his argument within the boundaries of this paper (for his relationship with Jung and Freud see János Kenyeres's excellent discussion in "Northrop Frye and contemporary literary theory," The Anachronist 1998, 248-266, pp. 252-254), but his main point is that the literary critic is interested in archetypes (or rather in myth which contains them) not as the source or origin of literature but as its content. It is one of Frye's basic convictions that the stubborn permanence of archetypal patterns cannot be adequately explained either historically or psychologically. Frye's assumption (on which he built his whole critical work) is that they are "continuously latent in the order of words" (Anatomy of Criticism, p. 109). His emphasis on the lack of any satisfying rational explanation for the order of archetypes strengthens my own point that Marius/Pater's search in the direction of religion is not necessarily an escape from a more radical and a more sincere point of view, but an integral necessity of being human.

35 Analysing his fifth fictional mode (irony) and pointing out that "the archetype of the incongruously ironic is Christ, the perfectly innocent victim excluded from human society," Frye comes to the very interesting conclusion that modern, ironic literature, which "begins in realism and dispassionate observation," "moves steadily towards myth, and dim outlines of sacrificial rituais and
} 
dying god figure is the archetypal basis for this curious paradoxical unity of the tragedy and irony of life, and the end of Marius the Epicurean one remarkable artistic expression of it. This closing episode also highlights one neglected aspect of the Christian tradition: the "accidental" death of Marius (archetypally: the death of Christ), as a metaphor for the death of the self exhibits a holy irony, a certain lightness and humour or easy detachment, with which the soul should relate to herself and to her situation here on earth. Needless to say, it is to Pater's artistic merit that both the tragedy and the irony of death (and of the human condition) bear equal weight here.

\section{THE GREAT POSSIBILITY}

As we have seen, this moment of visionary wholeness, this opening to things beyond is derived from the recreation of a myth. Myth here is understood in the sense described by Frye: it is a narrative which relates not to the actual, but to the possible (historically, myth is first religious, then, recreated by literature, it becomes poetical). It relates to the same lifting up of horizons that Marius desires, such a desire waging battle with his visual temperament ("he must still hold by what his eyes really saw" [p. 225]). In the words of Frye: "this may not be what you would have seen if you had been there, but what you would have seen would have missed the whole point of what was really going on." ${ }^{37}$ That Pater was preoccupied with the possible as an opening provided by both art and religion is clearly seen from Marius and other of his works as well. At the Roman feast preceding Marius's first visit to Cecilia's house, a Socratic dialogue (The Halcyone, once attributed to Lucian) is read out, in which Socrates says:

[...] methinks we are but half-blind judges of the impossible and the possible. We try the question by the standard of our human faculty, which avails neither for true knowledge, nor for faith, nor vision. Therefore many things seem to us impossible which are within our reach; partly through inexperience, partly through the childishness of our minds.

(pp. 220-221)

dying gods begin to reappear in it. Our five modes evidently go around in a circle. This reappearance of myth in the ironic is particularly clear in Kafka and Joyce." (Northrop Frye. Anatomy of Criticism, p. 42-43.)

${ }_{37}^{36}$ Northrop Frye. The Great Code, p. 49.

${ }^{37}$ Northrop Frye. The Great Code, p. 48. 
He then goes on to draw a parallel between the activity of the Deity, and the activity of the human artist to point out that there is no limit to what is possible.

In a similar manner, Frye talks paradoxically about faith as the reality of hope and of illusion, starting with "a vision of reality which is something other than history or logic, and on the basis of that vision it can begin to remake the world." ${ }^{38}$ In spite of his changing views, religion has remained for Pater the Great Possibility, the "sacred ideal" for the perfection of man. ${ }^{39}$ His vision of early Christianity is a vision of hope, a vision of the possible: the dream of the regeneration of humanity. Marius saw in the early church "that regenerate type of humanity, which, centuries later, Giotto and his successors [...] were to conceive as artistic ideal" (p. 235). Pater, in fact, detects a cyclical principle of dying and coming to life in the history of culture: the Renaissance being the eternal metaphor for the rebirth.

It was the old way of the true Renaissance - being indeed the way of nature with her roses, the divine way with the body of man, perhaps with his soul - conceiving the new organism by no sudden and abrupt creation, but rather by the action of a new principle upon elements, all of which had in truth already lived and died many times.

Analysing the Paterian vision, a multiplicity of levels can be identified: the mythic archetype of the dying god or Christ figure is reflected in the processes of nature (mythic or ritual level), in the fate of one man, Marius (personal level) and in the renewal of civilisation (level of cultural history, to do justice to Jules Lubbock as well).

\section{QUASI-MYSTICAL EXPERIENCE?}

The vision of Cecilia's house, which is at once a vision of artistic ideal and an opening towards the possible (the transcendent), is preceded and reinforced by Marius's strange spiritual experience through which he comes close to a kind of monotheistic faith. First he is pondering on the level of the intellect the

\footnotetext{
${ }^{38}$ Northrop Frye. The Double Vision: Language and Meaning in Religion. Toronto Buffalo London: University of Toronto Press, 1991, p. 63.

${ }^{39}$ In Gaston de Latour (1888) he is talking about "recognitions of a great possibility which might lie among the conditions of so complex a world." Walter Pater. Gaston de Latour. London: 1910, p. $112-13$.
} 
hypothesis "of an eternal friend to man, just hidden behind the veil of a mechanical and material order [...] ready perhaps even now to break through..." and then he actually experiences a presence: "some other companion, an unfailing companion, ever at his side throughout." "Must not the whole world around have faded away for him altogether, had he been left for one moment really alone in it?” (pp. 208-210). Then Marius identifies this presence with the being the Old Testament calls Creator, the Greek philosophers Eternal Reason and the New Testament the Father of Men. The experience is preceded by Marius's musings on the need for a communal but strongly personal basis for morality which I have examined earlier, thus it can also be seen as an ultimate answer to that need in the person of this "eternal friend to man," this "unfailing companion" (p. 210).

It is legitimate to interpret these experiences as psychological as long as the term is not used in an exclusive sense. All experience (aesthetic, religious, and emotional) is psychological in that it takes place within the human psyche. But on the basis of the text it does not seem justified to rule out right from the start a theological interpretation of Marius's experiences, claiming as Monsman does that this presence is first and foremost Marius's double, and his sense of identification with his double "provides an expanded consciousness of selfhood beyond the range of his personal experience." Monsman's claim, as well as McGrath's insistence on Marius's experience (and on Stephen's epiphanies in Joyce's Portrait) being "quasi-mystical," "clearly aesthetic and psychological rather than religious," betray the reduced perception of the full-fledged modern mind which excludes the possibility of a spiritual dimension. McGrath has written that Pater "deRomanticized German idealism [...] by rejecting its transcendental claims and applying its insights exclusively to the finite psychological world of individual experience. ${ }^{41}$ On the one hand, this statement eliminates one pole of the tension inherent in Pater's thinking. On the other hand, as I will show in the last section, the "individual experiences" recorded in the whole body of Pater's work suggest a recurring archetypal pattern and thus acquire a depth and a communal aspect largely lost to alienated modern man. Therefore, we do well to perceive a multiplicity of dimensions in Marius's ambiguous and complex experience, in which the ambiguity and the irony are, if you like, the modern elements.

One thing that can be known for sure about Marius's visions is that they have changed him, which again points outside the domain of pure aestheticism.

\footnotetext{
40 Gerald Monsman, p. 30.

${ }^{41}$ McGrath, p. 10.
} 
McGrath typically comments that after his experience in "The Will as Vision," Marius "quickly retreats to the relativistic world of the senses," 42 whereas in the text itself we read: "[...]the experience of that fortunate hour, seeming to gather into one central act of vision all the deeper impressions his mind had ever received, did not leave him quite as he had been" (p. 217, my italics). Of course this is a dramatic experience for Marius: after the encounter with Cecilia he struggles with the tension of his temperamental Epicureanism (being the eternal outsider) and the desire to become involved. For this eternal outsider, "the image of Cecilia, it would seem, was already become [...] like some matter of poetry, or of another man's story, or a picture on the wall" (p. 277), but the opposite desire is referred to more than once, and Marius indeed makes up his mind to do something, for the first time in his life of observation. In reality, he does two things: he tries to talk to Marcus Aurelius about the persecution of the church (but fails to see him), and finally he sacrifices himself for his friend, Cornelius.

\section{THE ACT OF SACRIFICE}

Marius's final act brings us back to the motif of death and the deepest existential and artistic paradox which accompanied Walter Pater throughout his work. There were two aspects to his worldview as an artist. One was the humanist ideal, the yearning for the perfection of man, for the "harmonious development of all the parts of human nature, in just proportion to each other" (p. 241). The other was the fact that he could not help expressing a much more desperate, dramatic view of humanness in his own art, a view of human nature as divided or split in itself. He objected to the latter in calling it asceticism: "moral effort as essentially a sacrifice, the sacrifice of one part of human nature to another, that it may live more completely in what survives of it" (p. 241), yet the act of sacrifice (which is in a way an ultimate and by no means harmonious answer to the human plight) has haunted him throughout his work. As we will see later, the pattern of sacrifice appears in his works as giving someone's life for the sake of another.

Temperamentally, Pater (and his hero, Marius) was attracted to the harmonious aspect of Christianity (which certainly has a place in the Christian tradition, as the theologian Richard Niebuhr pointed out in his book Christ and

${ }^{42}$ McGrath, p. 234. 
Culture $\left.^{43}\right)$. It was this aspect which later gave rise to humanism. In this view, Christ is the human ideal, and man can be perfected through his example; there is no forced opposition between the soul and the body, the church and the world, instead there is peace and harmonious development. ${ }^{44}$ Not surprisingly, Abélard, one of Pater's favourites, is listed in this category by Niebuhr. Nevertheless, such a cultural view of Christianity always remains in tension with more dramatic, and traditionally more significant theologies which place more emphasis on evil and the brokenness of man, and great art tends to display the same tension.

Pater's wish for harmony and for the realisation of full humanness necessarily led him away from the purely aesthetic experience of ecstatic perception towards the existential realm in which action has priority over perception. Full humanness calls for something more solid than the flux of impressions, and there are hints in Marius that this fullness is related to sympathy and love. In one of the last chapters preceding his death, Marius entertains the recurring thought of "a certain grief in things as they are" (p. 274), meaning primarily death, old age and evil in the world, as a kind of summary of his inquiries into the nature of reality. The only counterbalancing factor turning the scales in favour of harmony, concludes Marius, is the power of sympathy, or in stronger terms, love. "I would that a stronger love might arise in my heart," he exclaims (p. 274). He seems to be thinking of a certain equalisation: if one received as much as he gave in terms of care or love, this would compensate for what he has lost or suffered. Thus love between humans is the only way to "touch absolute ground amid all the changes of phenomena [...] touch the eternal" (p. 275). At the very end of his musings he refers to "one of those suffering yet prevailing deities, of which old poetry tells," and closes with the hope that "there is a heart, even as ours, in that divine Assistant of one's thoughts - a heart even as mine, behind this vain show of things" (p. 275).

Through delicate hints then, human compassion and love becomes a pointer to, or at least a hope for a suffering and loving divine heart. Considering the fact that in the remaining chapters attention will fully turn to Christ and Christian martyrdom, the paradox is fully stated: the way to harmony lies through disharmony. Love, in its cosmic function of the restoration of harmony,

\footnotetext{
${ }^{43}$ H. Richard Niebuhr. Christ and Culture. Harper and Row Publishers, 1975. He describes this particular kind of Christian attitude in the chapter "The Christ of culture" on pages 83-115.

it "Sociologically they [the 'cultural Christians'] may be interpreted as nonrevolutionaries who find no 'cracks in time' - fall and incarnation and judgement and resurrection." (H. R. Niebuhr, p. 84.)
} 
must necessarily be pursued to its extreme point, sacrifice. We can discern this paradoxical pattern of the human condition in some of Walter Pater's stories: in that of Amis and Amile; in the story of Sebastian van Storck, who dies while saving a child from drowning; and in the story of Marius who dies giving his life for his friend (which is the greatest expression of love, as the Gospel of John says). Such an act is paradoxically close to suicide and thus to a final negation of life (Van Storck's temptation), yet at the same time by imitating a divine pattern of love this is the supreme opening to "things beyond."

This antinomy at the heart of Pater's interpretation of reality is the clue to solving the "unexpected and incongruous tragedies which conclude his portraits. ${ }^{45}$ This also explains his attraction to the story about the friendship of Amis and Amile. The central motif of that story is vicarious sacrifice: first Amis takes Amile's place in a tournament, delivering him from death, then Amile, by the command of the angel Raphael, slays his own children to wash Amis, sick with leprosy, in their blood. This story illustrates for Pater the paradoxical fullness of the Renaissance, which "has not only the sweetness which it derives from the classical world, but also that curious strength of which there is great resource in the true middle age."

This significant statement well illustrates my main point: Pater's need as an artist and a human being to balance the Arnoldian "sweetness and light" of the classical world with the "curious strength" of the Christian pattern of sacrifice. I have stressed that Pater recoils from drama and crisis, yet all his works are dramatic, given that evil involves crisis, and the way to love through sacrifice involves crisis as well. Rather than being merely his personal dilemma, this is a general characteristic of the human condition. Thus, in the last section of Marius, Pater concludes by a ritual expression of this dilemma, condensing it in the archetypal Man, the Founder of Christianity:

And last of all came a narrative [...] displaying, in all the vividness of a picture for the eye, the mournful figure of him towards whom this whole act of worship still consistently turned - a figure which seemed to have absorbed, like some rich tincture in his garment, all that was deepfelt and impassioned in the experiences of the past.

\footnotetext{
${ }^{45}$ Gerald Monsman, p. 33.

${ }^{46}$ Walter Pater. "Two early French stories." The Renaissance, p. 10.
} 
Pater preferred the "Good Shepherd, serene, blithe and debonair, beyond the gentlest shepherd of Greek mythology; a king under whom the beatific vision is realized of a reign of peace" (p. 238). He preferred "born Christians" to those becoming Christians "under some sudden and overpowering impression, and with all the disturbing results of such a crisis" (p. 240). And yet, for Marius,

the most touching image truly that had ever come within the scope of his mental or physical gaze [...] was the image of a young man giving up voluntarily, one by one, for the greatest of ends, the greatest gifts; actually parting with himself, above all, with the serenity, the divine serenity of his own soul.

$$
\text { (p. 250, my italics) }
$$

This passage is, at the same time, a precise description of what Marius ends up doing. The eternal outsider, the Epicurean observer, parting with himself, with the serenity of his soul, identifies with his friend. He re-enacts the archetypal pattern. In his case, as I have said, the act is coloured by irony (in a sense, Marius is certainly a "martyr to honest uncertainty" ${ }^{\text {") }}$, and thus strikingly modern epistemological and existential anxieties are woven into the expression of something ancient and human.

\footnotetext{
${ }^{47}$ Michael Levey. "Introduction." Marius the Epicurean, p. 23.
} 